\title{
EARTHWORMS, ANTS AND OTHER ARTHROPODS AS SOIL HEALTH INDICATORS IN TRADITIONAL AND NO-FIRE AGRO-ECOSYSTEMS FROM EASTERN BRAZILIAN AMAZONIA
}

\author{
Guillaume Xavier Rousseau, ${ }^{1}$ Paulo Rogério dos Santos Silva, ${ }^{1}$ Cláudio José \\ Reis de CARVALHO ${ }^{2}$ \\ ${ }^{1}$ Graduate Program in Agroecology, Maranhão State University (UEMA), Cidade Universitária Paulo \\ VI S/N, Tirirical, São Luis-MA 65055-970, Brasil. Email: guilirous@yahoo.ca, rogeriobarrolandia@ \\ yahoo.com.br \\ ${ }^{2}$ Embrapa Amazônia Oriental, Tv. Dr. Enéas Pinheiro s/n, Marco, 66095-100 Belém PA, Brazil. \\ Email: carvalho@cpatu.embrapa.br
}

Rousseau, G. X., P. R. dos S. Silva, C. J. R. de Carvalho. 2010. Earthworms, ants and other arthropods as soil health indicators in traditional and no-fire agro-ecosystems from Eastern Brazilian Amazonia. Acta Zoológica Mexicana (n.s.), Número Especial 2: 117-134.

ABSTRACT. Deforestation of the Amazonian rainforest and conversion to agriculture with the use of fire creates a mosaic of occupied lands and secondary forests. Considering the fundamental role of soil macrofauna and the lack of information about its resilience to deforestation, this study characterized the earthworms, ants and other soil arthropod communities in secondary forests of 40 and 20 years of age and in cropping system and pastures prepared with slash-and-burn or chop-and-mulch in the Brazilian Eastern Amazonia. Soil macrofauna was sampled according to the TSBF (Tropical Soil Biological and Fertility) methodology. Four sub-indices and one "macrofauna soil health index" were calculated using five principal component analyses. The macrofauna index identified better soil health in chop-andmulch crops, followed by the $40 \mathrm{yr}$-old forest and the chop-and-mulch pasture. These results confirmed the fundamental role of old secondary forests for soil biodiversity conservation and the potential of the chop-and-mulch technique to mitigate the effects of land use changes.

Keywords: Soil macrofauna, biodiversity, principal component analysis, soil quality, soil management.

Rousseau, G. X., P. R. dos S. Silva, C. J. R. de Carvalho. 2010. Lombrices de tierra, hormigas y otros artrópodos como indicadores de la salud de los suelos en sistemas tradicionales y en agroecosistemas sin el uso del fuego en la Amazonia Oriental. Acta Zoológica Mexicana (n.s.), Número Especial 2: $117-134$.

Resumen. La deforestación de la selva húmeda en la Amazonia y su conversión para la agricultura con el uso del fuego crea un mosaico de tierras ocupadas y de bosques secundarios. Considerando el papel fundamental de la macrofauna del suelo y la falta de información sobre su resiliencia frente a la deforestación, este estudio caracterizó las comunidades de lombrices, hormigas y otros invertebrados del suelo en bosques secundarios de 40 y 20 años, en sistemas de cultivo con corte y quema o corte y trituración,

Recibido: 16/05/2008; aceptado: 08/01/2010. 
y en pastizales con corte y quema o corte y trituración en la Amazonia oriental brasileña. La macrofauna fue colectada según el método TSBF (Tropical Soil Biological and Fertility). Cuatro sub-índices y un "índice macrofauna de salud del suelo" fueron calculados a partir de cinco análisis de componentes principales. El índice macrofauna apuntó una mejor salud del suelo en el sistema de cultivo con trituración seguido por el bosque secundario antiguo (40 años) y el pastizal con trituración. Estos resultados confirman el papel fundamental de los bosques secundarios antiguos para la conservación de la biodiversidad del suelo y el potencial de la trituración para mitigar los efectos de los cambios en el uso del suelo.

Palabras clave: Macrofauna del suelo, biodiversidad, análisis de componentes principales, calidad del suelo, manejo del suelo.

\section{INTRODUCTION}

Processes of land-use changes are intense in Amazonia, mainly since the late 60's. The dominant pattern is the conversion of the native vegetation (rainforest or Cerrado, the Brazilian savanna) to agriculture by logging and burning. Cattle ranching and traditional slash-and-burn agriculture are the main land uses in deforested areas (Nepstad et al. 2001). However, low fertility of soils lead to abandonment (after 10-20 years) of areas converted to pasture (Alfaiai et al. 2004) and fallow (after 3-4 years) of lands converted for short cycle crops (Denich et al. 2005). As a consequence, the landscape that results from this colonization process is a mosaic of lands in agricultural use and secondary forests of various ages (Vieira et al. 1996). Even if the effects of land-use conversion on plant diversity are relatively well known (Vieira et al. 1996, Baar et al. 2000), little information is available about soil macrofauna diversity in Amazonia and about its resilience to deforestation (Mathieu et al. 2005). In this context, secondary forests (fallows) play a key role for soil (Dunn 2004) and plant biodiversity conservation (Vieira et al. 1996, Baar et al. 2000), but are poorly studied regarding soil fauna (Mathieu et al. 2005).

Considering the fundamental role of soil macrofauna and its diversity in soil functions (Lavelle et al. 1997, 2006, Ekschmitt \& Griffiths 1998), this study aimed at characterization of earthworms, ants and other invertebrates' communities under six land uses (two secondary forests, fields and pastures prepared with slash-and-burn or chop-and-mulch) of the Bragança region, Northeastern Pará state, in the Brazilian Amazonia. The first objective was to study the effects of land use on the invertebrate communities and their diversity through multivariate analyses and, the second objective was to construct sub-indices (one for each community and one for species richness and diversity) and an "integrated macrofauna index" to synthesize the multivariate approach and classify the land uses according to soil health.

\section{MATERIAL AND METHODS}

\section{Study area}

The sites sampled were at the Experimental Farm of the Federal Rural University of Amazonia (UFRA) and the Santa Luzia community, both located in Igarapé-Açu 
(Pará, Brazil). The climate is equatorial humid with mean annual temperature of 25$27^{\circ} \mathrm{C}$ and annual precipitation between 1700 and $2700 \mathrm{~mm}$. Soils were Ultisols (Typic Kandiudults) and the original native vegetation was a tropical humid evergreen to semi-deciduous forest.

\section{Experimental design}

Six land uses were evaluated for their impact on soil macrofauna: 1) 40 yr-old secondary forest (F40); 2) 20 yr-old secondary forest (F20); 3) slash-and-burn cropping system (SB); 4) chop-and-mulch cropping system (CM); 5) slash-and-burn prepared pasture (PSB); 6) chop-and-mulch prepared pasture (PCM). Cropping systems and forests plots had 2 ha each in size $(100 \times 200 \mathrm{~m})$ and were located at the UFRA Experimental farm while the pasture plots had 1.5 ha and were located in the Santa Luzia community. All plots for macrofauna sampling were installed in January 2006. Both cropping systems were prepared from a 15 yr-old secondary forest in November 2001 by traditional slash-and-burn (manual) or chop-and-mulch technology using an FM 1600 AHWI tractor-propelled chopper (O. Kato, personal communication). A fragment (about $5 \mathrm{ha}$ ) of the $15 \mathrm{yr}$ secondary forest was conserved as a control and used to install the $20 \mathrm{yr}$ secondary forest plot of 2 ha in 2006. Both systems were sown with maize (Zea mays) followed by cassava (Manihot esculenta) then, in July 2003, the slash/burn system return to natural fallow while in the chop/mulch system the fallow was enriched with fast-growing leguminous trees (Racosperma mangium [Willd.] Pedley and Sclerolobium paniculatum Vog.). The chop/mulch system was chopped again at the end of 2004 and sown with maize followed by beans (Phaseolus vulgaris) and then cassava until November 2006. The pastures were prepared in 2001 from a 12 yr-old secondary forest, in the same way as the cropping systems, and sown (February 2001) with Brachiaria humidicola and Brachiaria brizantha. From March 2002 to September 2005 the plots were grazed at $1.12 \mathrm{AU} /$ ha $(1$ Animal Unit $=$ one $450 \mathrm{~kg}$ animal), then the plots rested until September 2006. In February 2006, three transect lines of seven sampling points were positioned (on a regular grid of $25 \mathrm{~m}$ at UFRA experimental farm and 20-22 $\mathrm{m}$ in Santa Luzia) in each land-use plot. Macrofauna was sampled in March (rainy season) and September (dry season) 2006, only the rainy season results are presented here. Macrofauna was hand-sorted in $25 \times 25 \times$ $15 \mathrm{~cm}$ soil monoliths (TSBF; Anderson \& Ingram 1993), at each sampling point (21 monoliths per land use). Arthropods (and gastropods) were preserved in $80 \%$ alcohol and identified until genus for ants and order (maximum taxonomic level) for other arthropods. Worms were preserved in $4 \%$ formaldehyde and identified at genus level.

\section{Statistical analyses}

Total abundance of earthworms, ants (genera with density $>5$ ind. $\mathrm{m}^{-2}$ ) and other invertebrates along with species richness $(\mathrm{S})$ and Shannon diversity index (H') (from 
the 3 complete matrices of abundances) were calculated for each land use and submitted to nested analyses of variance (ANOVA), with transects as nested factor (Legendre 2002). Student-Newman-Keuls (SNK) multi-comparison tests were performed to separate land uses (Underwood 1997). Differences between land uses were considered significant at $P \leq 0.05$.

The three matrices of abundance (earthworms, ants, other invertebrates) plus the matrix of S and H' were submitted to Principal Component Analyses (PCA) with land uses as passive (binary) variables using CANOCO 4.5 program (ter Braak \& Smilauer 2002). According to Legendre and Gallagher (2001), species matrices that did not reach (or approach) multi-normality had to be transformed before PCA. Earthworm and other arthropods matrices were transformed into Hellinger distances while the ants matrix was transformed into "distance between species profile" (Legendre \& Gallagher 2001). Four principal components were retained for earthworms and ants while only two were retained for other matrices. Nested multivariate analyses of variance (MANOVA) were performed to test the effects of land use on the invertebrate communities (with transects as nested factor) (Legendre 2002).

\section{Macrofauna index of soil health (MISH) calculation}

Four sub-indices (earthworms, ants, other invertebrates and S-H') were calculated, based on PCA results and an integrated macrofauna index of soil health (MISH) was derived from them (adapted from Velásquez et al. 2007). To calculate the sub-indices, two or three PCA axes were considered (sum of axes eigenvalue $\geq 60 \%$ ). For each axis, the variables with contributions superior to half of the highest contribution were retained. These contributions were used to calculate the sub-index value for each object. The abundances retained were transformed according to the formula

$$
\mathrm{Y}=0.1+((\mathrm{x}-\mathrm{b}) /(\mathrm{a}-\mathrm{b}) * 0.9)
$$

where $\mathrm{Y}$ is the transformed variable, $\mathrm{x}$ is the variable to transform, $\mathrm{a}$ is the maximum and $b$ the minimum of variable $\mathrm{x}$. It was then assumed that invertebrate abundances were positively and linearly correlated with soil health. The transformed abundances were multiplied by their contribution on each axis and these products were summed. The sum was submitted to the above formula to produce a sub-index value between 0.1 and 1 . The four sub-indices were then submitted to a PCA and the final macrofauna index was calculated in the same way as the sub-indices (Velásquez et al. 2007). Nested ANOVA (Legendre 2002) and SNK multi-comparison tests were performed to test the effect of land uses on indices (Underwood 1997). Differences between land uses were considered significant at $P \leq 0.05$. 


\section{RESULTS}

\section{Total abundances, species richness and Shannon diversity index}

The earthworm abundance varied from 177 in F40 to 787 ind. $\mathrm{m}^{-2}$ in PCM and was significantly higher in the chop/mulch systems compared with F40 and SB. PSB and F20 had intermediate abundances (Fig. 1). Ant abundance varied from 216 in PSB to 977 ind. $\mathrm{m}^{-2}$ in F40 and had the greatest variability among samples ( 0 to 8304 ind. $\mathrm{m}^{-2}$; data not shown). No significant differences were detected between land uses (Fig. 2). The abundance of other invertebrates varied from 480 in SB to 3131 ind. $\mathrm{m}^{-2}$ in F40 and land uses were separated in two significantly different groups: F40, CM and PCM had the highest abundances (Fig. 3). Earthworm richness was significantly different between PCM (2.9) and F20 (1.7) while the other uses had intermediate values not significantly different (Fig. $4 \mathrm{a}$ ). Shannon diversity had the same pattern but F40 was the most diverse (0.72) and F20 the least (0.25) (Fig. 4b). Ant richness was greatly and significantly higher in F40 (6.5) compared to the other uses (2.6 to 3.7) (Fig. 4a). Shannon diversity followed a similar pattern, but F20 and SB had intermediate diversity ( 0.84 and 0.82$)$ between F40 (1.31) and other uses ( 0.58 to 0.72$)$

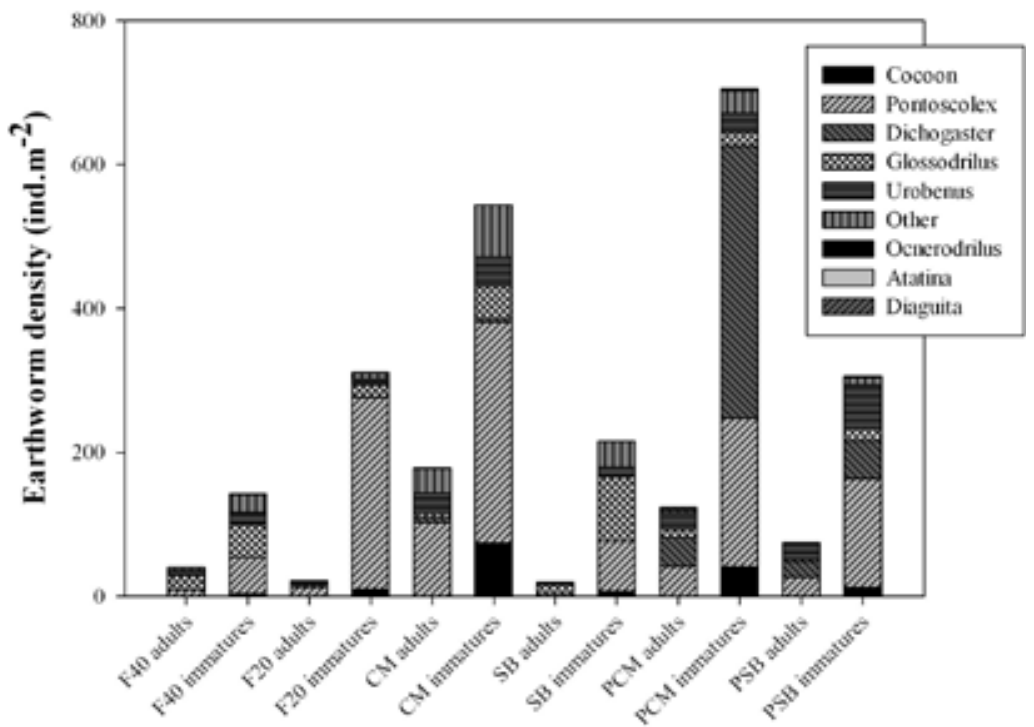

Land uses

Figure 1. Abundance of adult and immature earthworm genera for six land uses in Igarapé-Açu soil (Pará, Brazil), March 2006 (rainy season). CM: chop/mulch crops; SB: slash/burn crops; F20: 20 yr secondary forest; F40: $40 \mathrm{yr}$ secondary forest; PCM: chop/mulch pasture; PSB: slash/burn pasture.

Earthworm genera abundance in bars are in ascending order: Cocoon-Diaguita. Total abundances with different letters are significantly different at $P \leq 0.05$. 


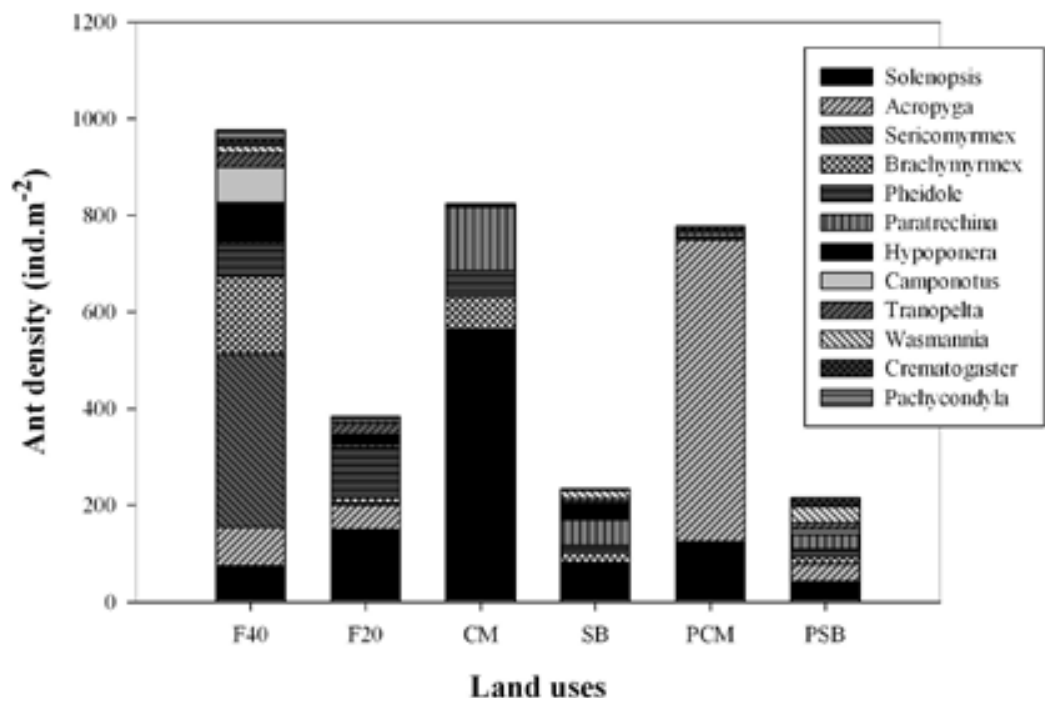

Figure 2. Abundance of ant genera (only genera with $\geq 5$ ind. $\mathrm{m}^{-2}$ ) for six land uses in Igarapé-Açu soil (Pará, Brazil), March 2006 (rainy season). Ant genera abundance in bars are in ascending order:

Solenopsis-Pachycondyla (cf. Fig. 1 for details).

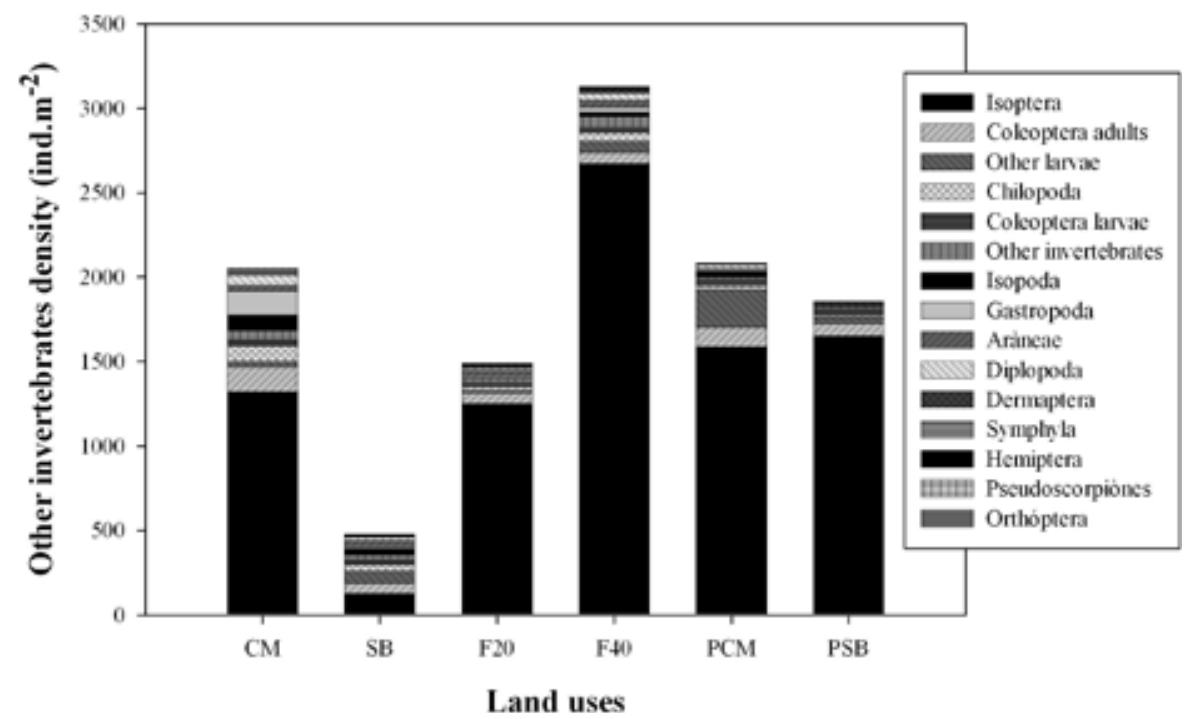

Figure 3. Abundance of other invertebrates for six land uses in Igarapé-Açu soil (Pará, Brazil), March 2006 (rainy season). Other invertebrates abundance in bars are in ascending order: Isoptera-Orthoptera (cf. Fig. 1 for details). 

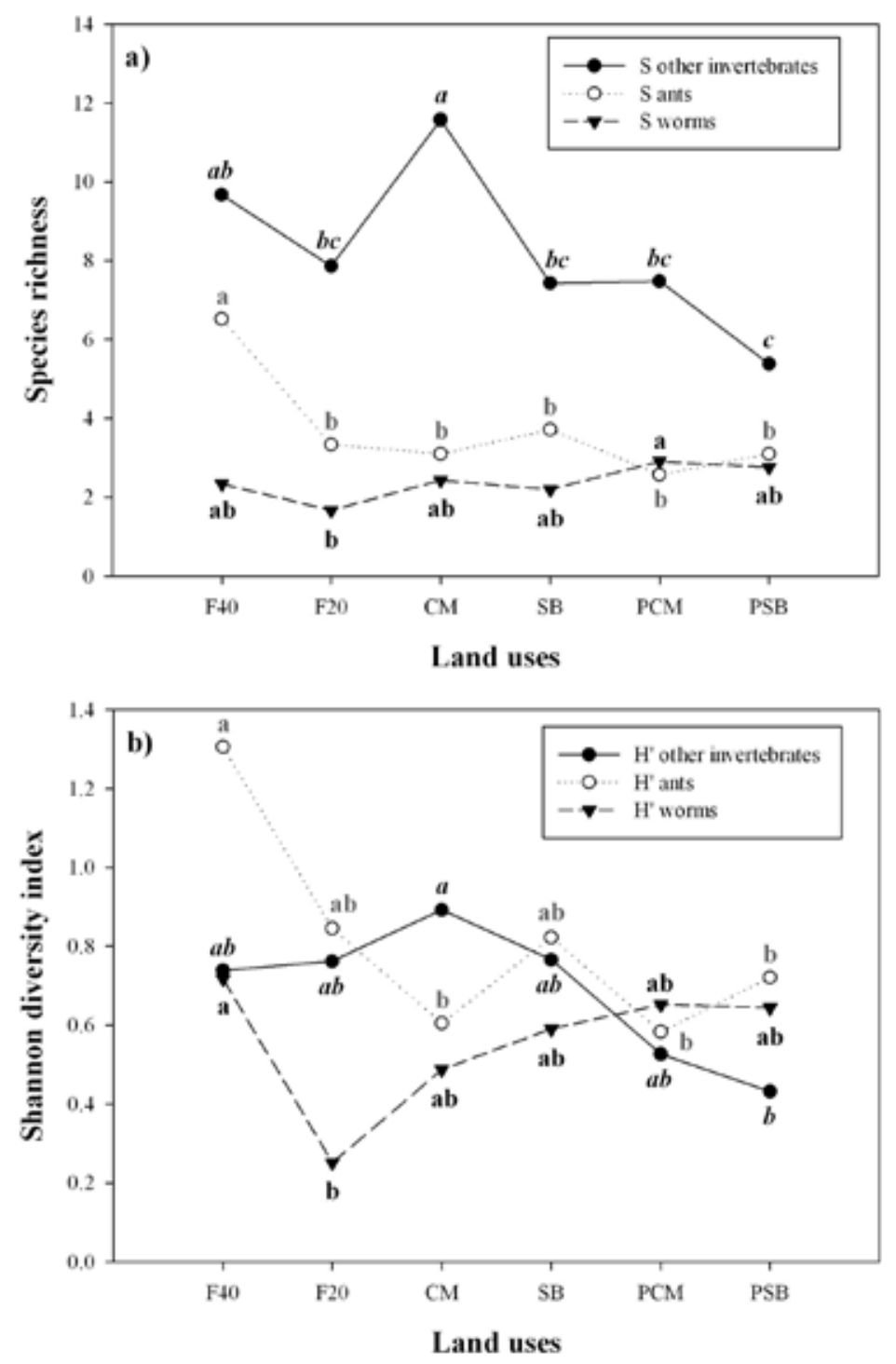

Figure 4. Species richness (S) a) and Shannon diversity index $\left(\mathrm{H}^{\prime}\right)$ b) of earthworms, ants and other invertebrates for six land uses (cf. Figure 1 for details) in Igarapé-Açu soil (Pará, Brazil), March 2006 (rainy season). S and H' means with different letters are significantly different at $P \leq 0.05$.

(Fig. 4b). The richness of other invertebrates was significantly higher in CM (11.6) than in any other land use, except F40 that had intermediate richness (9.7) (Fig. 4a). Diversity was also the highest in CM (0.89) but all uses, excepted PSB (0.43), had intermediate diversity (Fig. 4b). 
Rousseau et al.: Invertebrates as soil health indicators in Amazonia

Table I. Nested MANOVA and principal component analysis (PCA) of land uses and transects (nested) on soil macrofauna matrices from Igarapé-Açu soil (Pará, Brazil) in March of 2006.

\begin{tabular}{|c|c|c|c|c|c|}
\hline \multirow[t]{2}{*}{ Matrix/Season } & \multicolumn{2}{|c|}{ Land uses } & \multicolumn{2}{|c|}{ Transects } & \multirow{2}{*}{$\frac{\text { PCA (4 axes) }}{\% \text { total variance }}$} \\
\hline & $\%$ total variance & $P$ & $\%$ total variance & $P$ & \\
\hline \multicolumn{6}{|l|}{ Rainy season } \\
\hline Earthworms & 22.9 & $0.001 * *$ & 10.5 & $0.007 * *$ & 66.6 \\
\hline Ants & 14.6 & $0.001 * *$ & 10.1 & 0.11 & 73.9 \\
\hline Other macrofauna & 21.1 & $0.001 * *$ & 5.9 & 0.88 & 79.1 \\
\hline Richness/Diversity & 26.7 & $0.001 * *$ & 11.4 & $0.01 *$ & 95.5 \\
\hline
\end{tabular}
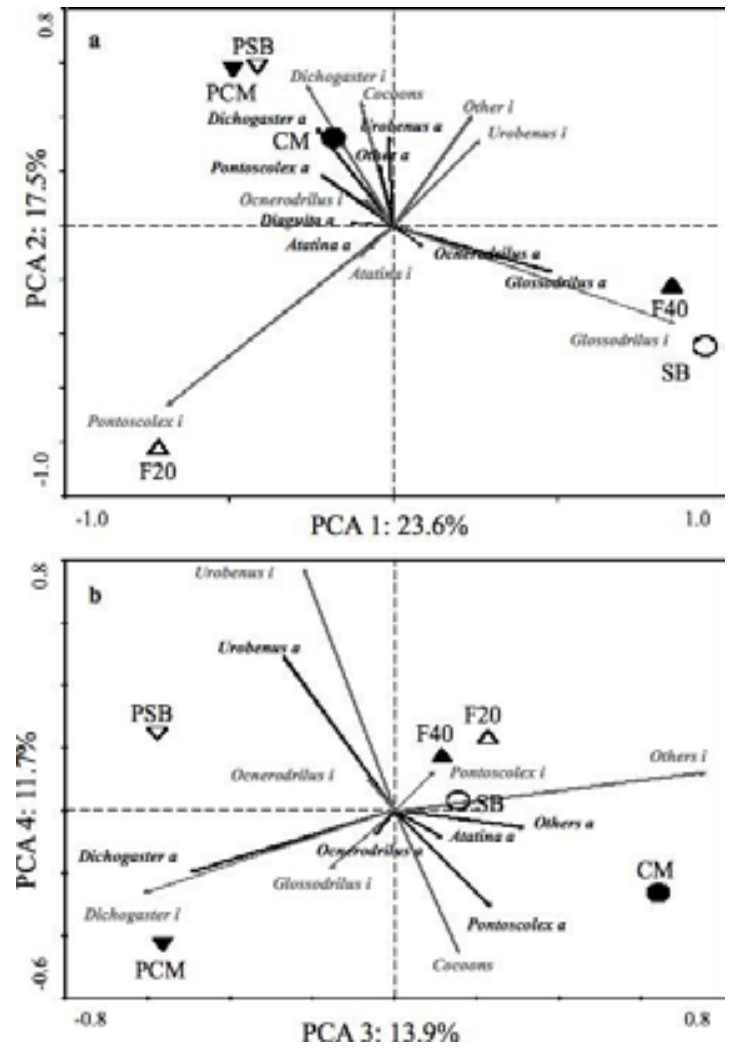

Figure 5. Principal component analysis on earthworm genera (adults $=a$, immature $=i$ ) and cocoons from Igarapé-Açu soil (Pará, Brazil, March 2006), for six land uses (passive nominal variables): 40 and $20 \mathrm{yr}$ secondary forests (F40/F20), chop-and-mulch/slash-and-burn prepared crops (CM/SB), chop-and-mulch/slash-and-burn prepared pastures (PCM/PSB). a) PCA 1 (23.6 \%) and 2 (17.5\%); b) PCA $3(13.9 \%)$ and $4(11.7 \%)$. 


\section{Principal Component Analyses}

Eight earthworm genera were identified and they explained $66.6 \%$ of total variability while land uses explained $22.9 \%$, according to the PCA. The earthworm community was significantly different among land uses according to the MANOVA $(P<0.001)$ (Table I). On axis 1, Glossodrilus (adult and immature) associated with F40 and SB, and was opposed to Pontoscolex (immature) that was associated with F20. On axis 2, Pontoscolex (immature) and Glossodrilus associated with forests and SB, were opposed to other genera (including Pontoscolex adult) that were associated with pastures and CM (Fig. 5a).
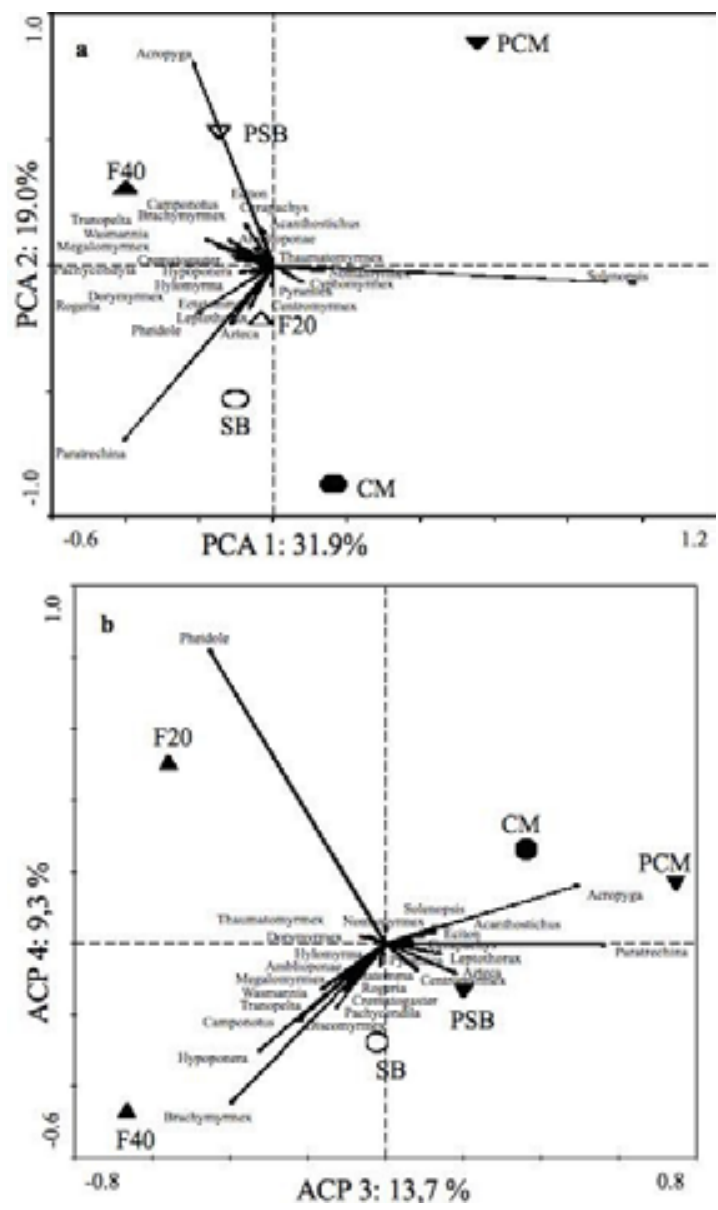

Figure 6. Principal component analysis on ant genera from Igarapé-Açu soil (Pará, Brazil, April 2006), for six land-uses (passive nominal variables). a) PCA 1 (31.9\%) and 2 (19.0\%); b) PCA 3 $(13.7 \%)$ and $4(9.3 \%)$ (cf. Fig. 5 for details). 
The axis 3 opposed Pontoscolex (adult and immature) and other (unidentified) genera associated with CM, to Dichogaster (adult and immature) associated with PCM. The axis 4 opposed Urobenus (adult and immature) associated with PSB, to worm cocoons and Pontoscolex (adult) associated with PSB and SB (Fig. 5b).

Forty-one ant genera were identified but only 27 were conserved in the PCA. They explained $73.9 \%$ of total variability while land uses explained $16.3 \%$. The ant community was significantly different among land uses according to the MANOVA $(P<0.001)$ (Table I). The axis 1 opposed Solenopsis associated with CM and PCM, to most other genera and all other land uses. The axis 2 opposed Acropyga associated with PSB and PCM, to Paratrechina associated with SB and CM (Fig. 6a).

The axis 3 opposed Paratrechina and Acropyga associated with CM and PCM, to Pheidole, Brachymyrmex and Hypoponera that were associated with F20 and F40. The axis 4 opposed Pheidole associated with F20, to Brachymyrmex and Hypoponera associated with F40 (Fig. 6b).

In addition to earthworms and ants, 19 invertebrate groups were identified (13 retained in PCA). They explained $79.1 \%$ of total variability while $21.1 \%$ was explained by land uses, according to the PCA. The community of other invertebrates was significantly different among land uses according to the MANOVA analysis $(P<0.001)$ (Table I). The axis 1 opposed the termites associated with F40 and PCM,

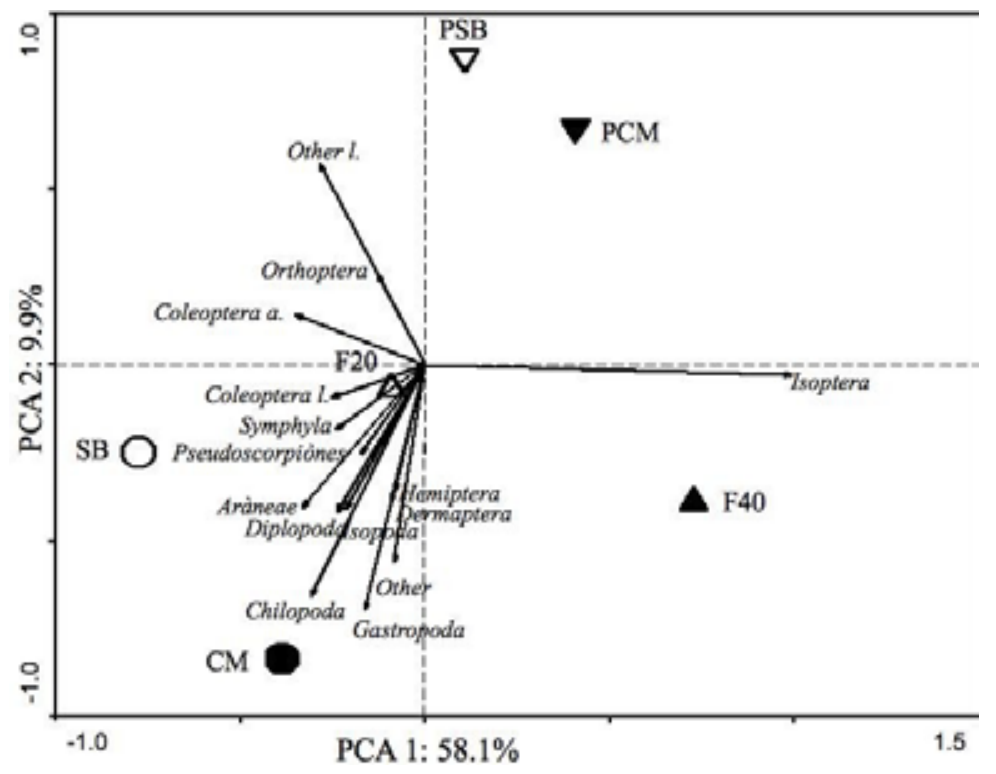

Figure 7. Principal component analysis, axes 1 (58.1\%) and 2 (9.9\%), on other macrofauna groups from Igarapé-Açu soil (Pará, Brazil, March 2006), for six land uses (passive nominal variables) (cf.

Fig. 5 for details). 
to all other groups associated with SB and CM. The axis 2 opposed unidentified larvae and Orthoptera associated with PSB and PCM, to litter-living groups associated with CM, F40 and SB (Fig. 7).

The PCA on species richness (S) and Shannon diversity index (H') explained $95.5 \%$ of total variability, while $24.3 \%$ was explained by land uses. Species richness and diversity of invertebrate communities were significantly different among land uses according to the MANOVA $(P<0.001)$ (Table I). The axis 1 represented $\mathrm{S}$ and $\mathrm{H}^{\prime}$ gradient and opposed F20 and pastures to F40. The axis 2 opposed earthworms S and $\mathrm{H}^{\prime}$ associated with PSB and PCM, to the invertebrates $\mathrm{S}$ and $\mathrm{H}^{\prime}$ associated with F20 and F40 (data not shown).

\section{Macrofauna index of soil health (MISH)}

According to the earthworm index of soil health and ANOVA, soil health was significantly better in CM $(0.45)$, followed by PCM $(0.35)(P<0.001)$. The ant index detected no significant difference $(P=0.084)$ in soil health among land uses while the "other invertebrates" index identified significantly better soil health for CM (0.38), followed by F40 $(0.32)(P<0.001)$. Species richness and diversity index was significantly higher in F40 (0.73) compared to all other land uses $(P=0.047)$. The integrated macrofauna index identified $\mathrm{CM}$ as the significantly better land use $(0.58)$ followed by F40 (0.51) and PCM (0.43) $(P=0.006)$ (Table II).

\section{DISCUSSION}

To our knowledge, this is the first time that soil macrofauna community is characterized with such details in North-Eastern Amazonia and particularly in North-Eastern Pará state, the oldest colonization front in Amazonia (Vieira et al. 1996). A previous study conducted in Igarapé-Açu (Leitão-Lima \& Teixeira 2002) during the dry season evaluated only the soil surface litter macrofauna in chop-mulch systems with improved fallows including several leguminous trees. Ants were the dominant group both in terms of abundance and biomass, probably as a result of the collection date (dry season) and sample location (litter).

Due to the lack of taxonomical information for the region, studies usually use para-taxonomy (Mathieu et al. 2004) and rarely identification at the species level (Mathieu et al. 2005), particularly when several major taxonomic groups are studied. In the present study, two major groups (earthworms and ants) were studied until genus level with the help of one specialized taxonomist per group, while the other groups encountered were identified only superficially (order was the maximum taxonomic level). This intermediate level of identification was a trade-off between the use of para-taxonomy that is not fully trustable when species overlap is expected (Krell 2004), and the excessive time and difficulties expected to identify all the animals at the species level. 


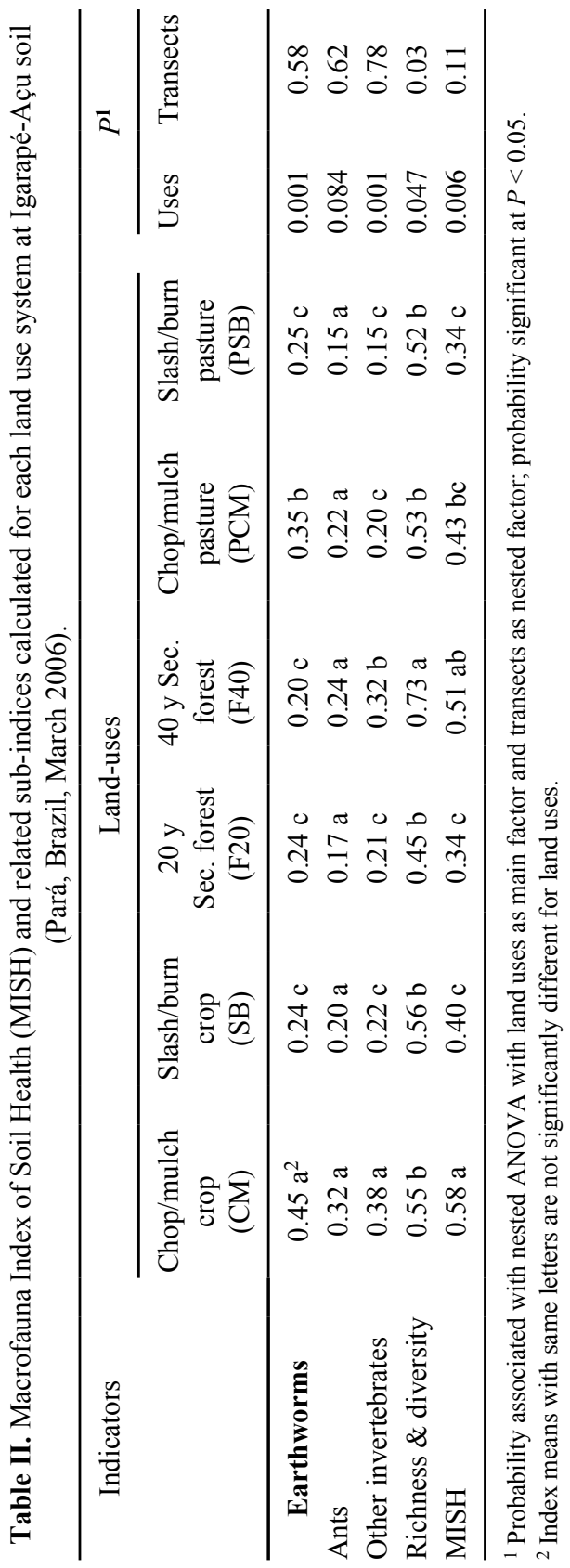


The relative precision of the community description led to the separation of the invertebrates in three matrices plus a matrix for richness and diversity, in order to maximize the potential of each major group to discriminate land uses for their impacts on soil macrofauna communities. As the PCA allowed only the characterization of the structure of each community among land uses, there was a need to synthesize the ecological information in a way that would make it more accessible to the land users, technicians or policy makers (Velásquez et al. 2007). For this purpose we adapted the Global Index of Soil Quality (GISQ) proposed by Velásquez et al. (2007). The GISQ was proposed to combine the information on macrofauna communities and physico-chemical soil attributes to give to each site studied an estimation of soil quality (synonymous of soil health; USDA 2004) through a unique and synthetic metric. We applied the process to combine the information of the three macrofauna matrices plus the species richness and diversity to calculate an integrated "Macrofauna Index of Soil Health" (MISH) that was complemented by an ANOVA on the integrated index and each sub-index. As a result, the adaptability of the GISQ mentioned by the authors was confirmed, and the utility of the index was improved by coupling with ANOVA. Indeed, ANOVA and multi-comparison tests on the indices allowed separating precisely the land uses according to their effect on the different communities as on the whole macrofauna community, which was not achieved with MANOVA.

\section{Principal Components Analysis (PCA)}

In the PCA on worm genera, explained variability was gradually divided between the first four axes $(23.6,17.5,13.9$ and $11.7 \%$ of total variability) and allowed to identify the main trends of the land use effect on the earthworm community (Fig. 5). The first axis is the more difficult to interpret as it opposed the Glossodrilus genera populations, that dominate F40 and SB, to a huge immature Pontoscolex (Pontoscolex $i$ ) population in F20. The genera Glossodrilus seems to tolerate pretty well slash-andburn as it shows similar populations in the oldest forest and the youngest (SB plot was a $4 \mathrm{yr}$ fallow at sampling time) which experimented a relatively recent (4.5 yr) burning. The immature Pontoscolex population encountered in the $20 \mathrm{yr}$-old forest probably reflects a seasonal effect (sampling occurred during the wetter period of the year) along with the history of the forest fragment. Indeed, this forest showed evidences of recent illegal logging that modified locally the forest cover (illegal wood extraction is very common in the region; Margulis 2004) and older modifications in the soil as remnants of graveled road, evidenced by local soil compaction and texture modification (data not shown).

The evidence of soil importation on the site may help explain the dominant nature of the Pontoscolex population, as this genus is considered invasive and associated 
with human activities (Barros et al. 2002, Brown et al. 2006). The second axis clearly separated the open (pastures and CM) vs. closed environments (forests and SB). Open environments were associated to more genera richness while forests and fallow were dominated by Glossodrilus and immature Pontoscolex (Fig. 1, 5a). The third axis opposed the pastures to all other land uses because of the presence of Dichogaster, an exotic genus from Africa (Blakemore 2002), which is present almost exclusively in the pastures (only a few individuals in $\mathrm{CM}$ ) and was sampled preferentially in association with the $B$. brizantha root net (up to 381 individuals per soil monolith; data not shown) (Fig. 1, 5b). In Amazonian pastures, B. brizantha root net was already reported as attractive for soil macrofauna (Mathieu et al. 2004). The fourth axis represented the effect of chop-and-mulch on the earthworm community and confirmed that the main genera (Pontoscolex, Dichogaster and Glossodrilus) benefited from this practice (Fig. 5b). The worm community was thus very useful to separate the land uses despite unidentified seasonal and/or soil texture effects detected on the first axis. Worms were particularly sensitive to the vegetation cover, the effect of pasture and of chop-and-mulch, but they appear to be little sensitive to the slash-and-burn as practiced in the region (or recover efficiently).

The PCA on ants was dominated by a few genera while most had low contribution to the axes (short arrows) (Fig. 6). To help in the interpretation of the ant community structure among land uses, genera were classified according to their ecological habits (Fernandez 2003). Although this classification was devised for the Cerrado (no such classification is available for Amazonian rainforest ants) it was consistent with the present results. On first axis Solenopsis, classified as an omnivorous soil genus, separated the chop-and-mulch land uses from the others. This genus seems well adapted to the open environment with soil rich in bulk organic matter provided by chop-and-mulch (Fig. 2, 6a). On axis 2 Acropyga and Paratrechina separated the pastures from the crops. Acropyga is classified as a soil specialist and was the dominant genus in pasture, suggesting a good adaptation to the compacted soils with little or no litter. On the contrary, Paratrechina, classified as soil and vegetation opportunist, abounded in the crops that had thick $(1.7-7.7 \mathrm{~cm})$ and diversified (Sá \& Carvalho 2005) mulch with cassava cover in CM and thin litter $(0.9-5.7 \mathrm{~cm})$ with dense fallow vegetation in SB (Fig. 6a). On the third axis Pheidole, Brachymyrmex, Camponotus and Hypoponera (principally) separated the secondary forests from the other land uses and chop/mulch plots in particular. The fact that the first three genera are classified as vegetation opportunists (Camponotus can also be classified as a "patrolling generalist", Fernandez 2003) reflect the switch in vegetation cover from open or fallow systems to real forest cover while the higher abundance of predator specialist Hypoponera (or the "big epigeic predators" Pachycondyla and Ectatomma) indicate a higher ecosystem "maturity" (Odum 1969, Neutel et al. 2007) (Fig. 6b). On the 
fourth axis Pheidole characterized F20 while Brachymyrmex and the predator genera were associated with F40, thus confirming the higher maturity of the old secondary forest (Fig. 6b).

The PCA of the other invertebrate groups had only two relevant axes with most of the variability explained by the first axis (58.1 of 79.1\%) (Fig. 7). The first axis reflects the abundance of termites in the more "natural" environment (F40) and the more disturbed systems (pastures) while most of the groups were epigeics (litterliving) and concentrated in the chop/mulch prepared crop (Fig. 3, 7). Mathieu et al. (2005) reported that termites were the invertebrates that best recovered (together with earthworms) after the conversion of Amazonian forests to pasture (after six years). In Africa (Cameroon), termite communities were similar in secondary and primary forest in several studies (Eggleton et al. 1996, Eggleton et al. 2002). The second axis represented mainly the effect of litter as the pastures were clearly separated from the other land uses and associated with soil-living larvae (Other 1. and Orthoptera). Litter-living communities were thus associated firstly to CM and then to SB and showed high abundance of predator groups as Chilopoda, Araneae, Dermaptera and Pseudoscorpiones, showing that mulch supports an abundant and mature litter community (Fig. 3, 7). Indeed, the mulch provided soil protection and food supply establishing an environment similar (or better) to the fallow vegetation (Mathieu et al. 2005).

The PCA on species richness and Shannon diversity index was the most explicative (Table 1) and confirmed that the old secondary forests have a well developed macrofauna structure that is more similar to that of mature ecosystems, with the highest richness and diversity of ants, the highest diversity of earthworms and also high richness and diversity of others invertebrates (Fig. 4). In Southern Pará, Mathieu et al. (2005) showed that forest fallows contained similar soil macrofauna species richness and diversity (Shannon index) to the primary forest after only seven years. However, the plots studied experienced only one fire and were converted from primary forest very recently (less than $10 \mathrm{yr}$ previous) (Mathieu et al. 2005).

The effect of pastures on worm abundance and richness may be attributed to the shorter turn-over of organic matter provided by grazing, the easily-decomposing litter and the favorable environment provided by Brachiaria root-net for some genera (Mathieu et al. 2004). As a matter of fact, earthworm proliferation after forest conversion to pasture has often been reported in Amazonia, but is often associated to large populations of the invasive species $P$. corethrurus (Lavelle \& Pashanasi 1989, Höfer et al. 2001, Barros et al. 2002). In the pastures of this study diversity and richness were very high, perhaps due to the equilibrium between Dichogaster (exotic and potentially invasive) and Pontoscolex populations and/or the presence of adjacent secondary forest that may act as diversity source. 


\section{Macrofauna Index of Soil Health (MISH)}

The integrated index and sub-indices provided a synthesis of the PCA results, while combined abundance and diversity allowed a significant separation of land uses depending on their impacts on macrofauna communities. Chop-and-mulch systems had high indices mainly due to their positive effect on invertebrate abundance, while the old secondary forest indices were high due to the species richness and diversity. The ant index was the only one that did not detect significant differences between land uses, probably because the index retained only five ant genera in the variable selection (data not shown), thus suggesting a limitation in the use of the index when rare species dominate the community. Indeed, PCA is not devoted to select a subset of the most discriminant variables from a large data set. The use of discriminant analysis or canonical redundancy analysis to perform a finer selection of the variables that best explain the differences between land uses could be helpful to solve this problem in future analyses (Legendre \& Legendre 1998). Despite this possible limitation, the MISH was consistent with the results of the PCA analysis and is a promising tool to allow a more accessible evaluation of soil quality based on macrofauna to a non-specialized audience. However, special attention must be paid to the nature of relationship between the indicator variables and soil health. Indeed, in the MISH as in the GISQ (Velásquez et al. 2007), all the indicator variables were considered to be linearly related with soil health (positively related in the case of macrofauna). This could be misleading in some occasions for macrofauna, for example with proliferation of soil compacting worms as P. corethrurus (Barros et al. 2004), but it is more critical for a range of physical and chemical indicators that usually do not show linear relationships with soil health (Andrews et al. 2002).

As a conclusion, the MISH proved to be useful in separating the land uses but still needs to be fully tested and eventually refined, to provide reliable indication of soil health. The effect of chop-and-mulch was decisive on the abundance of all groups, with emphasis on earthworms, compared to the slash-and-burn systems and limited the decrease in diversity of arthropods (excluding ants). However, chop-and-mulch had no or little effect on ants and earthworms richness and diversity. Ant richness and diversity greatly benefited from the secondary forests of both ages, while earthworms had more diverse populations in the pastures and similar diversity in pastures and old secondary forest. These results confirmed the fundamental role of old secondary forests in the conservation of soil biodiversity and the potential of chop-and-mulch systems to mitigate the effects of land use changes. Indeed, the land use mosaic created by smallholder agriculture has proved to support high biodiversity in this study as in former ones (Baar et al. 2000, Hecht 2005, Mathieu et al. 2005) and should be maintained and improved to reconcile food production and forest conservation. The role of chop-and-mulch could then be decisive to improve sustainability in Amazonia if the technique is used to conserve soil health and reduce the pressure on primary and old secondary forests. 


\section{ACKNOWLEDGEMENTS}

The authors are grateful to the Conselho Nacional de Desenvolvimento Científico e Tecnológico (CNPq) and to the IEB/programa de pequenos apoios for their financial support. We also would like to gratefully thank O. Kato and all the staff of the Embrapa Amazônia Oriental Tipitamba project for their logistic support, along with Reginaldo Farias and his team in Igarapé-Açu for their skills.

\section{LITERATURE CITED}

Anderson, J. M. \& J. S. I. Ingram. 1993. Tropical soil biology and fertility: a handbook of methods. $2^{\text {nd }}$ ed. CAB International, Wallingford.

Andrews, S. S., D. L. Karlen \& J. P. Mitchell. 2002. A comparison of soil quality indexing methods for vegetable production systems in northern California. Agriculture Ecosystems and Environment. 90: 25-45.

Alfaiai, A. S., G. R. Ribeiro, A. D. Nobre, R. C. Luizão \& F. J. Luizão. 2004. Evaluation of soil fertility in smallholder agroforestry systems and pastures in western Amazonia. Agriculture Ecosystems and Environment. 102: 409-414.

Baar, R., M. D. R. Cordeiro, M. Denich \& H. Fölster. 2000. Floristic inventory of secondary vegetation in agricultural systems of East-Amazonia. Biodiversity and Conservation. 13: 501-528.

Barros, E., B. Pashanasi, R. Constantino \& P. Lavelle. 2002. Effects of land-use system on the soil macrofauna in western Brazilian Amazonia. Biology and Fertility of Soils. 35: 338-347.

Blakemore, R.J. 2002. Cosmopolitan earthworms - an eco-taxonomic guide to the peregrine species of the world. VermEcology, Kippax.

Brown, G. G., S. W. James, A. Pasini, D. H. Nunes, N. P. Benito, P. T. Martins \& K. D. Sautter. 2006. Exotic, peregrine and invasive earthworms in Brazil: diversity, distribution and effects on soils and plants. Caribbean Journal of Science. 42: 339-358.

Denich, M., P. L. G. Vlek, T. D. D. A. Sá, K. Vielhauer \& W. Lücke. 2005. A concept for the development of fire-free fallow management in the Eastern Amazon, Brazil. Agriculture Ecosystems and Environment. 110: 43-58.

Dunn, R. R. 2004. Recovery of faunal communities during tropical forest regeneration. Conservation Biology. 18: 302-309.

Ekschmitt, K. \& B. S. Griffiths. 1998. Soil biodiversity and its implications for ecosystem functioning in a heterogeneous and variable environment. Appied Soil Ecology 10: 201-215.

Eggleton, P., D. E. Bignell, S. Hauser, L. Dibog, L. Norgrove \& B. Madong. 2002. Termite diversity across an anthropogenic disturbance gradient in the humid forest zone of West Africa. Agriculture Ecosystems and Environment. 90: 189-202.

Eggleton, P., D. E. Bignell, W. A. Sands, N. A. Mawdsley, J. H. Lawton, T. G. Wood \& N. C. Bignell. 1996. The diversity, abundance and biomass of termites under differing levels of disturbance in the Mbalmayo Forest Reserve, Southern Cameroon. Philosophical Transactions of the Royal Society of London, Series B-Biological Sciences. 351: 51-68.

Fernández, F. 2003. Introducción a las hormigas de la región Neotropical. Instituto de Investigación de Recursos Biológicos Alexander von Humboldt, Bogotá.

Hecht, S. B. 2005. Soybeans, development and conservation on the Amazon frontier. Development and Change. 36: 375-404.

Höfer, H., W. Hanagarth, M. Garcia, C. Martius, E. Franklin, J. Römbke \& L. Beck. 2001. Structure and function of soil fauna communities in Amazonian anthropogenic ecosystems. European Journal of Soil Biology. 37: 229-235. 
Krell, F. T. 2004. Parataxonomy vs. taxonomy in biodiversity studies - pitfalls and applicability of 'morphospecies' sorting. Biodiversity and Conservation. 13: 795-812.

Lavelle, P., D. Bignell, M. Lepage, V. Wolters, P. Roger, P. Ineson, O. W. Heal \& S. Dhillion. 1997. Soil function in a changing world: the role of invertebrate ecosystem engineers. European Journal of Soil Biology. 33: 159-193.

Lavelle, P., T. Decaëns, M. Aubert, S. Barot, M. Blouin, F. Bureau, P. Margerie, P. Mora \& J. P. Rossi. 2006. Soil invertebrates and ecosystem services. European Journal of Soil Biology. 42: S3-S15.

Lavelle, P. \& B. Pashanasi. 1989. Soil macrofauna and land management in Peruvian Amazonia (Yurimaguas, Loreto). Pedobiologia. 22: 283-291.

Legendre, P. 2002. Nested Anova user's guide. Département de sciences biologiques, Université de Montréal, Montréal. [On line] http://www.fas.umontreal.ca/biol/legendre/.

Legendre, P. \& E. D. Gallagher. 2001. Ecologically meaningful transformations for ordination of species data. Oecologia. 129: 271-280.

Legendre, P. \& L. Legendre. 1998. Numerical ecology. $2^{\text {nd }}$ ed. Elsevier, Amsterdam.

Leitão-Lima, P. S. \& L. B. Teixeira. 2002. Macrofauna do solo em capoeiras natural e enriquecidas com leguminosas arbóreas. Embrapa Amazônia Oriental, Comunicado Técnico No. 62, Belém.

Margulis, S. 2004. Causes of Deforestation in the Brazilian Amazon. World Bank working papers, Washington D.C.

Mathieu, J., J. P. Rossi, M. Grimaldi, P. Mora, P. Lavelle \& C. Rouland. 2004. A multi-scale study of soil macrofauna biodiversity in Amazonian pastures. Biology and Fertility of Soils. 40: 300-305.

Mathieu, J., J. P. Rossi, P. Mora, P. Lavelle, P. F. S. Martins, C. Rouland \& M. Grimaldi. 2005. Recovery of soil macrofauna communities after forest clearance in Eastern Amazonia, Brazil. Conservation Biology. 19: 1598-1605.

Nepstad, D., G. Carvalho, A. C. Barros, A. Alencar, J. P. Capobianco, J. Bishop, P. Moutinho, P. Lefebvre, U. L. Silva Jr. \& E. Prins. 2001. Road paving, fire regime feedbacks, and the future of Amazon forests. Forest Ecology and Management. 154: 395-407.

Neutel, A. M., J. A. P. Heesterbeek, J. van de Koppel, G. Hoenderboom, A. Vos, C. Kaldeway, F. Berendse \& P. C. de Ruiter. 2007. Reconciling complexity with stability in naturally assembling food webs. Nature 449: 599-602.

Odum, E. P. 1969. The strategy of ecosystem development. Science. 164: 262-270.

Sá, T. D. A. \& C. J. R. Carvalho. 2005. Alterações em componentes do balanço de carbono e na emissão de gases traço em função da substituição do sistema de produção agrícola de cortelqueima pelo de corte/trituração/manejo de capoeira. Projeto Milênio LBA, Relatório do subprojeto 5. Embrapa Amazônia Oriental, Belém.

ter Braak, C. J. F. \& P. Smilauer. 2002. CANOCO reference manual and CanoDraw for Windows User's guide: Software for Canonical Community Ordination. Version 4.5. Microcomputer Power, Ithaca.

USDA (United States Department of Agriculture). 2004. Glossary of soil quality terms. Soil Science Society of America, Madison. [On line] http://soils.usda.gov/sqi/soil_quality/what_is/glossary. html.

Velásquez, E., P. Lavelle \& M. Andrade. 2007. GISQ, a multifunctional indicator of soil quality. Soil Biology and Biochemistry. 39: 3066-3080.

Vieira, I. C. G., N. A. Rosa, D. C. Nepstad \& J. C. Roma. 1996. O renascimento da floresta no rastro da agricultura. Ciência Hoje. 20: 38-45. 